\title{
THE EASY WAY OUT? CONSTITUTIONAL AVOIDANCE AND ITS IMPACT ON HUMAN RIGHT ENFORCEMENT IN BOTSWANA
}

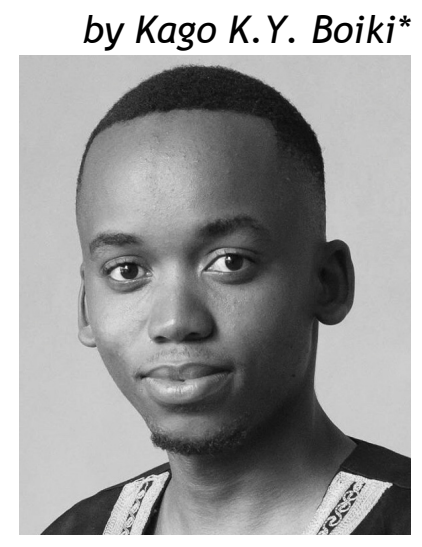

\section{Introduction}

Injustices occasioned by one person or entity on another can be remedied through the justice system. Parties who seek justice may approach courts of law to seek relief. However, when dealing with constitutional claims a more robust system exists in guiding litigants on procedure and possible remedies. Whether the courts allow for such claims and remedies however is still highly contentious matter, given the various doctrines the courts have adopted when dealing with constitutional matters.

Chief Justice Marshall once remarked: 'It is emphatically the province and duty of the judiciary to say what the law is.' 1 This proposition is all well and good, but it must be remembered that it is the province and duty of the legislature to say what the law should be. The limitations, sometimes self-imposed on the powers of any arm of government, especially the judiciary, have seen to have unmistakable consequences.

* LLB (University of Botswana), PGCert Risk Management, LLM Candidate (International Trade and Investment Law at the University of Pretoria) Attorney of Law admitted to the Bar (Botswana) Notary Public and Conveyancer. This article is aimed at promoting a critical analysis of the methods employed by the courts in executing their mandate.

1 Marbury v Madison 5 US (1 Cranch) 137 (1803) Chief Justice John Marshall. 
This article seeks to examine the doctrine of constitutional avoidance and assess whether it has had an impact on the protection of Human Rights in Botswana through the courts. This article will begin with the definition the doctrine of constitutional avoidance. This will be followed by an overview of Botswana's constitution and its Human Rights framework. The article will then go on to discuss the application of constitutional avoidance in Botswana, highlighting some case law that has been instrumental in the development of the doctrine of constitutional avoidance.

\section{Constitutional avoidance}

As a concept applied in the courts, the constitutional avoidance doctrine is a doctrine of statutory construction that states that 'when the validity of an act ... is drawn into question, and even if a serious doubt of constitutionality is raised ... the court will first ascertain whether a construction of the statute or any other is fairly possible by which the question may be avoided. ${ }^{2}$ It is courtesy of this definition that the concept has been afforded life over the decades. The doctrine effectively allows for the courts to avoid resolving serious constitutional disputes and issues by adopting even the narrowest interpretation of a statute.

The doctrine has been thoroughly examined in more developed nations, with jurisprudence which is rich in human right protections, which extend as far as socio- economic rights. ${ }^{3}$ The United States of America (USA) has been one of these nations, with its implementation leaving a lasting impact on the jurisprudence and the effectiveness of their federal judicial system. ${ }^{4}$ Within the Roman Dutch common law jurisdictions, it has been stated as the court's opinion that, the rules of avoidance were applicable at any stage as they are deeply entrenched in precedent. ${ }^{5}$ Furthermore, it has been said that the avoidance doctrine provides the courts with a method of preserving constitutional values without making unnecessary binding constitutional decisions. ${ }^{6}$ Should the courts be prone to lean towards

2 Ashwander $v$ Tennessee Valley Authority, 297 US at 288 (1936), (Brandeis, J, concurring).

3 J Dugard 'Beyond blue moonlight: The implications of judicial avoidance in relation to the provision of alternative housing' (2014) 5 Constitutional Court Review at 267.

4 MH Redish \& KL Drizin 'Constitutional federalism and judicial review: The role of textual analysis' (1987) 1 NYUL REV at 15.

5 Swaziland High Court, Vide Jerry Nhlapo and 24 others v Lucky Howe NO (in his capacity as Liquidator of [VIF] Limited in Liquidation). See also Civil Appeal No 37/07, Daniel Didabantu Khumalo v The Attorney General; Civil Appeal 31/2010, Lomvula Hlophe (on behalf of Acting Chief Ntsetselelo Maziya v Office In-Charge, Big Bend Correctional Institution) and 4 Others, Civil Case 2799/08.

6 RW Scheef 'Temporal dynamics in statutory interpretation: Courts, Congress, and the Canon of constitutional avoidance' (2002) University of Pittsburgh Law Review at 558-560 
making constitutional declarations, they run the risk of rewriting statute and possibly leaving a lacuna in the legislation. This is an obvious consequence should the challenged legislation be declared unconstitutional and thereby nullified, or even failing in totality to protect and preserve the constitutional norms at stake. It is arguable that the continued use of the doctrine allows for manipulation of the court system, in order to achieve desirable political outcomes, where a more favoured interpretative technique would lead to unfavourable results. This would in essence imply the incapability of the courts to establish a proper balance in implementing the doctrine. In other words, the courts' application of the doctrine would be grossly misguided by the eagerness of some jurists to make such declarations.

The Honourable Justices Annandale, Mabuza and Mamba JJ of eSwatini, justified the continued use of the doctrine, attributing it to the courts prudential desire not needlessly reach constitutional determinations in its decision. ${ }^{8}$ The court outlined the necessity of its use in adjudication of constitutional matters, and through this perspective, the use of the doctrine can be viewed as an exercise of judicial restraint. ${ }^{9}$ The question therefore arises whether it is prudent for a qualified judicial body to be willing to publicly abstain from fulfilling its mandate, which can be argued to be amongst other things, making constitutional pronouncements, and restraining itself through a self-imposed doctrine from fulfilling such mandate?

\section{Botswana's Constitution}

The Constitution of Botswana, has been credited for its promotion of democracy and affording all citizens equal rights. ${ }^{10}$ This is partly due to it having been able to maintain a stable, open and transparent democracy since independence. ${ }^{11}$ In its interpretation, it is abundantly clear that the framers of the constitution intended on the ensured protection of all human rights. ${ }^{12}$ Although socio-economic rights amongst others were excluded from explicit protection by the drafters at the time, this could have partly been due to the probable ignorance of the significance of the importance of such rights at the time. Socio-economic rights have been read into existence through a

7 Rust v Sullivan, 500 US 173, 204-05 (1990) (Blackmun, J, dissenting).

8 Nombuyiselo Sihlongonyane v Mholi Joseph Sihlongonyane (470/2013A) (2013) SZHC 144

9 As above.

10 Constitution of the Republic of Botswana Cap 0000 of 1966. See also Human Rights in Botswana, Ditswanelo, (2007).

11 CM Fombad 'Protecting constitutional values in Africa: a comparison of Botswana and Cameroon' (2003) 36(1) The Comparative and International Law Journal of Southern Africa at 83-105.

12 Diau v Botswana Building Society 2003 (2) BLR 409 (IC). 
broad interpretation of the civil and political rights provided for in the constitution. 13

As one of the three arms of government, the judiciary is undoubtedly the arm of government tasked with the protection of such rights as guaranteed in the constitution, through its interpretation and enforcement. The judiciary has been responsible for the judicial enforcement of socio-economic rights and has done so with satisfactory effectiveness and independence although, some of its decisions are questionable following applications by litigants. ${ }^{14}$

In a number of recent landmark decisions alongside other interpretative techniques, the courts have adopted a doctrine of constitutional avoidance in their approach to determine cases with major constitutional implications. This trend was seemingly first established in the recent Attorney General $v$ Thuto Rammoge and 19 Others case (hereafter 'LEGABIBO') judgment, which was followed by the Tapela v Attorney General (hereafter 'ARV') case. ${ }^{15}$

Historically, constitutional avoidance was understood to be a method of resolving interpretive ambiguities: if there are two equally plausible readings of a statute, and one of them raises constitutional concerns, judges readily chose the one which did not question the constitution. ${ }^{16}$ Several decisions of the High Court and Court of Appeal have been seen to have been decided on this doctrine. These courts have effectively shown their reluctance to bind the jurisprudence to precedents, which effectively make final determinations on highly contested constitutional questions as was shown in the cases discussed later in this article. In the USA, where the principle of constitutional avoidance is used to safeguard not only constitutional integrity but also federalism, jurists, scholars, and practitioners have criticised decisions made through the adoption of such a doctrine, claiming that they amount to unaccountable judicial conduct and prevent the growth of constitutional jurisprudence. ${ }^{17}$

Although it is clear that the doctrine adopted by the courts is not favoured by human rights activists, scholars and jurists, its continued implementation raises a series of concerns such as the inadequate protection of the fundamental rights of individuals and the failure of the courts to fulfil its mandate when issues of human rights protection

13 BR Dinokopila 'The justiciability of socio-economic rights in Botswana' 57(1) Journal of African Law at 108-125.

14 RA Kumar 'Constitutional rights and judicial activism: Bridging the gaps in Botswana' in E Quansah and W Binchy (eds) The Judicial Protection of Human Rights in Botswana (2009) 121.

15 Court of Appeal Civil Case No CACGB-128-14 delivered 16 March 2016, Court of Appeal Civil Case No CACGB-096-14; Attorney General and Others v Mwale, Court of Appeal Civil Case No CACGB-076-15 delivered 26 August 2015.

16 A Nolan 'The doctrine of constitutional avoidance: A legal overview' (2014) 2.

17 WK Kelley ‘Avoiding constitutional questions as a three-branch problem' (2001) 86 Cornell Law Review 846-60. 
are questioned. The implications of adopting the doctrine of constitutional avoidance in the courts may have a direct correlation with the protection of human rights in Botswana. This thereby brings into question the obligations of the judicial arm of government and questions whether they have been fulfilled through the adaptation of this doctrine; and also, whether the continued implementation of the doctrine amounts to responsible judicial activism.

\section{An overview of the protection of human rights in Botswana}

Civil and political rights guaranteed under the constitution are afforded to all individuals within Botswana's jurisdiction. It has been consistently argued and reported that Botswana has maintained a good human rights protection record relative to most African counterparts although, the constitution lacks in express provisions for socio-economic rights. ${ }^{18}$

\subsection{Constitutional provisions}

The constitution makes provision, under chapter II, for the preservation and protection of civil and political rights also referred to as first generation rights. ${ }^{19}$ After over fifty years of its application, the Constitution still reflects greatly on its originating influences such as, the European Convention on Human Rights, and is steadfast in so far as remaining one of the very few African constitutions that has not had an amendment of its bill of rights since enactment is concerned. ${ }^{20}$ Sections 3 to 15 of the Constitution provide for most of the civil and political rights. Section 3 is the umbrella provision for the rights embodied in chapter II. ${ }^{21}$ Anti- discrimination sentiments in the enjoyment of basic human rights are clearly expressed in the constitution as per the grounds so listed.

Botswana is party to several international and regional human rights instruments. These include but are not limited to, the International Covenant on Civil and Political Rights (ICCPR), the Convention on the Elimination of All Forms of Discrimination against Women (CEDAW) and the African Charter on Human and Peoples' Rights (ACHPR).

However, due to the fact that Botswana is a dualist state in its implementation and application of international instruments, treaty

18 Kumar (n 14) 121

19 Constitution of the Republic of Botswana (n 10) Chapter 2.

20 Dinokopila (n 13) 110.

21 EK Quansah 'Law, religion and human rights in Botswana' (2008) 8/2 African Human Rights Journal at 491. 
provisions do not become part of the laws of Botswana unless, specifically incorporated into the laws of Botswana through an act of Parliament. ${ }^{22}$

The Constitution under section 18, allows for the High Court of Botswana, to make determinations on the protection of rights entrenched under the Constitution. Therefore, for any alleged violations of sections 2 through 16 of the constitution, the aggrieved individual(s) may apply to the said court for redress. The court is further endowed with inherent jurisdiction in all instances of human rights violations which are brought under the said section 18. Should litigants be unhappy with decisions of the High Court they may appeal to the Court of Appeal thus, making it the final court within the jurisdiction which is capable of making determinations on Human rights issues.

The national case law is rife with constitutional questions that the Court has avoided whilst applying the doctrine, only to later on hold in favour of the constitutional challenge, when forced to confront the question under a different statute, where the constitutional challenge would succeed. It is in that light that the conduct of the courts, in so far as their interpretive techniques are concerned, are given significance, as they have an inevitably lasting impact on the human rights environment within the country. The courts are also seen as the most effective remedy in a peaceful democracy and the neglect of this role can only lead to anarchy. The doctrine of constitutional avoidance has been adopted by the courts and has left inescapable consequences, the most significant of them being that major constitutional questions remain unanswered, thereby allowing for the perpetuation, in some instances, of human right violations. The courts have further missed various opportunities in reshaping the human rights perspective within the country leading to a never-ending cycle of constitutional challenges over very similar issues, which were distinguished and manipulated by the courts so as not to receive constitutional attention and challenges by the candidates.

\section{Constitutional avoidance in Botswana}

Recently the decisions of the Botswana courts of record, the Court of Appeal and the High Court are of considerable interest in the growth of our constitutional law jurisprudence, alongside the constitution making and interpretation mechanisms within the jurisdiction. ${ }^{23}$ However, in reaching their decisions, it is arguable that the courts

22 Good v The Attorney-General (2) 2005 (2) BLR 337 (CA) 354.

23 The Attorney General $v$ Rammode and Others No CACGB-128-14. See also The Attorney General and Others $\vee$ Tapela and Others No MAHGB-000057-14, CACGB096-14. 
made determinations which were underwhelming in so far as making constitutional determinations is concerned, as the courts clearly and expressly adopted the doctrine of constitutional avoidance in their final judgements.

\subsection{History of avoidance in Botswana}

Following Motshegwa Busang $v$ The State, there was an indication of the adoption of the doctrine of constitutional avoidance in Botswana. ${ }^{24}$ The court reached the decision to adopt the doctrine in order to establish its position and ultimate desire to prevent itself from appearing to be posturing its power, thereby ultimately appearing as an opponent of the government. The court thereby chose to abandon its traditionally accepted role as a watchdog of justice in ordinary litigation. 25

When tackling the issue of failing to address constitutional questions raised during litigation, Presiding Judge His Lordship Maisels $\mathrm{P}$, in referring to precedent from the American jurisdiction stated:

In the United States of America, the Supreme Court has refused to pronounce decisions upon constitutional questions unless it has been absolutely compelled to do so in the particular case. Its reason for so doing is to minimize the possibility of conflict between it and the executive or the legislature ... With respect, I consider this to be the proper approach and one that this court should follow ... ${ }^{26}$

Although the learned justice chose not to elaborate any further on the issue in this instance, the decision left an impact on the judicial structure as it was the first indication of the adoption of a reasonable rationale for adoption of the doctrine of constitutional avoidance.

In this very sensitive era of our jurisprudence where the protection and enforcement of rights has taken great strides, neighbouring nations, in adopting the same doctrine, found fresh reason to apply the doctrine of constitutional avoidance. This position taken by the courts protected the peace between the arms of government and ensured that neither was seen to be overstepping and

24 Criminal Appeal of 1981 at 15- A complainant before a lower customary court was from an aggrieved person in terms of section 37 of the Customary Court (Act No 1 of 2006) Cap 04:05, for the purpose of Appeal to the Higher Customary Court. The reception of evidence in such an appeal is not an irregularity. The appellant was acquitted by a Subordinate Tribal Authority on a charge of stock theft. The complainant appealed to the Bamangwato Senior Customary Court and after a full re-hearing of the evidence the appellant was convicted.

25 A van Blerk 'The Botswana Court of Appeal: A policy of avoidance' (1985) 18(3) The Comparative and International Law Journal of Southern Africa at 385-395

26 This statement of the principle first appeared in Crowell $v$ Benson, 285 US 22, 62 (1932) (per Hughes, CJ). Mr Justice Frankfurter has related the principle to the 'case and controversy' rule, though conceding that the defect is not jurisdictional. See United States v CIO, 335 US 106, 126 (1948) (concurring opinion); cf. Cohens v Virginia, 6 Wheat. 264, 441 (US 1821). 
undoing the work of the other. Through the case of $S v$ Marwane, a South African court showcased its willingness to invalidate the provisions statue following determinations of unconstitutionality. ${ }^{27}$ When commenting on this decision in the later decision of Smith $v$ Attorney-General, Chief Justice Heimstra stated:

The Marwane case is a typical example of over-eager invalidation leaving a large lacuna in a country's legislation as it stood at the time of the relevant proceedings. The good was thrown out with the bad although the bad played no part in the relevant decision ... A Bill of Rights is not a wide-open door to the invalidation of legislation." 28

The learned Chief Justice continued to present his view on the delicate balancing process which is required in this dimension of constitutionalism. This being done in order to avoid resentment of the judiciary by the legislature as a result of an overzealous judiciary, which was quick to nullify statutes and in effect nullifying Acts of the legislature which were not in any stretch of the imagination easy to implement. He stated:

The Court helps to shape the Declaration of Human Rights with great deference to the Legislature. A Court which is over-active in striking down legislation can destroy the exalted instrument it is trying to bring to life, it can incur the resentment of the Legislature and cause the Declaration, which was meant to be a charter of freedom to become a clog upon the wheels of government. That must be avoided for the sake of the Constitution itself and for the sake of the statute of Parliament as the highest law-making forum of the nation. ${ }^{29}$

It was through these decisions that a clear intention to cement the doctrine of constitutional avoidance was clearly illustrated in the South African lower courts, although the constitutional court has never shown any intention to shy away from its responsibility in that regard. This stance would thereby be a decision which would have consequence on Botswana's courts as they borrowed jurisprudence from their neighbours as persuasive precedent.

\subsection{The first landmark decision}

Similar to many other legal principles and doctrines, the existence of the doctrine of constitutional avoidance truly came to light in Botswana in the land mark decision of State $v$ Petrus and Selaola. ${ }^{30}$

2719823 SA 717 (A), split bench 7-4. In the particular instance provisions of the South African Terrorism Act were nullified even though they fell under the protection of the same constitution as the new constitution expressly declared that only post-constitutional law would be subject to being nullified and declared unconstitutional.

2819841 SA 196 (B) of 199 to 200. See also van Blerk (n 25) at 385-395.

29 Smith v Attorney- General, Bophuthatswana [1984] 1 SA 176 (B)

30 Criminal Appeal 34 of 1983. 
This case was brought to light following the two accused persons being convicted by a senior magistrate in Francistown, in December 1982, for the offence of housebreaking and theft in contravention of section 305(1)(a) of the Botswana Penal Code. ${ }^{31}$ Two months prior to their conviction, in October, section 305(1)(a) had been amended. ${ }^{32}$ The amendments to the act fundamentally altered the prescribed sentences for the offences and the execution of the sentences. ${ }^{33}$ In accordance with the amended legislation the accused were each sentenced to three years' imprisonment and to corporal punishment as described in, the new section 301(3). On review, Hannah $\mathrm{J}$ in the High Court, suspended two years of the imprisonment but reserved for the Court of Appeal issues for determination related to the interpretation of the amended sections in the Penal Code and the mandatory nature of the sentences to be imposed. ${ }^{34}$ The accused person's attorneys then made an application alleging the prescribed sentence contravened the constitution which protects against torture and inhumane treatment.

The court then reconstituted to ensure that an adequate quorum was presented in dealing with the constitutional challenges raised. Following the mutual consent of the parties, the court then prepared to hear arguments and make determinations related to the questions posed to it.

The attack on the constitutionality of section 301(3) was directed at two aspects: the provision that the corporal punishment be administered in instalments and the provision that it be administered in the traditional manner, with traditional instruments, as had been the norm.

With due regard and in respect of the first aspect, the Court of Appeal was clear in its finding that the provision for repeated and delayed infliction of strokes flew in the face of section 7(1) of the constitution. This determination was based on the clear evidence of mental anguish of anticipated violence which had been viewed by varying jurisdictions as an inhumane and degrading punishment. ${ }^{35}$

31 Penal Code had come into effect as a Proclamation of the Bechuanaland Protectorate in 1964.

32 Botswana Penal Code Act 20 of 1982.

33 Amendments to the Penal code were closely followed by amendments to the Criminal Procedure and Evidence Act (By Act 21 of 1982, Act originated as a proclamation of Bechuanaland Protectorate, in 1938) which in essence prescribed methods of executing said corporal punishment which were inclusive of its administration in instalments. (Section 301(3) of Criminal Procedure and Evidence Act).

34 State $v$ Petrus and Selaola (review case 51 of 1983). See also Petrus and Another $\checkmark$ The State 1984 BLR 14 (CA) para 18.

35 Tyrer $v$ United Kingdom (1978) 2 EHHR 1 (the Isle of Man). 
The court however changed its tone with respect to the second challenge, as it proved to be less equivocal in respect of the second aspect; on whether the infliction of strokes in the traditional manner, with a traditional instrument was in conflict of section 7 of the constitution. The question was not without considerable importance and weight as any declaration by the court that such method of whipping was unconstitutional would have meant that the legislature could not re-enact it to retain a traditional, pre-constitutional form of punishment, the imposition of which was lawful in terms of the derogatory clause, section 7(2).

This landmark case had gained interest as being the first in Southern Africa in which corporal punishment had been challenged on the ground that it is degrading or inhumane. ${ }^{36}$ The decision however showcased the court openly holding back in giving a teleological interpretation to the constitution on two issues: first, the question whether the provision that corporal punishment be administered in traditional manner with traditional instrument was in conflict with section 7 of the constitution and, second, the question whether the imposition of corporal punishment per se or corporal punishment, in addition to a term of imprisonment was in conflict with section 7 of the constitution.

An assessment of the case however, shows to be fair as it cannot be said that the courts' chosen approach is without benefits. It has been shown that the court would have been critiqued for abusing its powers had it made determinations on matters that had not been brought before it. The absence of a final determination however, leaves room hopefully for the courts to remedy the situation should the question be raised again.

\subsection{The judicial position}

When it comes to the powers of the judiciary, the conventional view is that this wing of the government interprets the Constitution and other laws, and applies them. While deciding a particular case, the judge has to interpret the relevant law and apply the same to the facts, in order to reach a verdict. A specific legal provision can be interpreted in different ways. It may also happen that the same law is interpreted by different judges in different ways. While some judges stick to the plain text, others try to decipher the intent of the law and apply it accordingly. Others however, seek to rely on precedents set by their predecessors.

The application of the doctrine of constitutional avoidance has recently been used in land mark decisions by the High Court and Court 
of Appeal in establishing a precedent on issues of constitutional significance. The recent decision of Attorney General and Others $v$ Tapela and Others, popularly known as the ARV case, set a precedent in favour of the application of the doctrine of constitutional avoidance in a rather elaborative fashion. ${ }^{37}$

This case emanated from a 2004 internal directive by Botswana's Secretary of Health, which was circulated to public medical facilities informing them of a Presidential Directive authorising 'provision of free treatment to non-citizen prisoners suffering from ailments other than AIDS.' The two prisoners who were both diagnosed as HIVpositive in prison were denied ARV treatment although their physical conditions met the treatment criteria under the government's Treatment Guidelines. The government denied them ARV treatment as per its policy on the basis that they were not citizens.

HIV-positive non-citizen prisoners filed lawsuits through their representatives challenging this directive after being denied free Anti-Retroviral Therapy (ARVs). They argued that the refusal to provide ARVs contravened the National Policy on HIV and AIDS, which mandated the government to provide basic health care to prisoners, and that it violated the rights to life and non-discrimination, and constituted inhuman and degrading treatment under sections 4, 3,15 and 7 of the Constitution. The HIV-positive prisoners and the Botswana Network on Law and HIV/AIDS (BONELA) further challenged the Botswana government's refusal to cover the cost of ARVs for noncitizen prisoners. The case was consolidated with an appeal against contempt proceedings through which another HIV-positive non-citizen prisoner sought to enforce the lower court's order that, non-citizens meeting the treatment criteria be provided with ARVs.

\subsection{The High Court decision}

When deciding the matter following the conclusion of procedural disputes, the court began by affirming the science of ARV treatment. In the course of his judgment, Sechele $\mathrm{J}$ made several findings on the evidence that affirm the rationality and importance of ARV treatment. It held that ARVs are 'not only a medical necessity but a life-saving therapy the withholding of which will take away the constitutionally guaranteed right to life., 38 The Court further set an important precedent in pointing out the state's obligations towards prisoners, regardless of their citizenship status. In line with international standards, the Court held that inmates retain the residuum of their human rights when their liberty is taken away. 
The Court further held that the Prisons Act (hereafter 'the Prisons Act') imposes upon prison authorities the obligation to not only take measures to 'restore the health of prisoners' but also to 'prevent the spread of disease. ${ }^{39}$ This is a valuable interpretation to insist that preventative measures that vital, even though their use would effectively be seen as an admission by the prison officials that sexual activities occur in their facilities. The Court continued to hold that the limit on the rights of non-citizens under the Constitution is only justifiable if it is reasonable in a democratic society and is in the public interest. The Court held that it could never be justifiable in a democratic society to deprive a group of persons of life-saving treatment as such deprivation would result in them becoming more infectious to others thereby risking the enjoyments of their rights.

The court in this instance was unrelenting and clear in applying the protective provisions of the constitution in protecting the rights of the individuals concerned. The judgment was valuable for future public interest litigation in Botswana and set an important precedent in establishing a human rights-based approach to the treatment of foreigners and prisoners. However, in the appeal of the matter the court in that instance took a varying approach.

\subsection{Avoidance in action at the Court of Appeal}

In making its ruling, the court, upheld parts of the High Court decision. ${ }^{40}$ The court however rejected the government's arguments on permissible discrimination, the violation of separation of power principles and resource constraints. First, the Court found that because the directive was not a law and because the Prisons Act and Regulations forbid discrimination, the directive was not 'reasonably justifiable' in the public interest or to protect the rights of others. ${ }^{41}$

With reference to the lower court's decision which had rested on constitutional grounds, the Court of Appeal cautioned against reading socio-economic rights into the Botswana Constitution which does not guarantee such rights, including the right to health. Accordingly, the court narrowly limited its holding to non-citizen prisoners being entitled to medical treatment due to the provisions of the Prisons Acts rather than reading a right to health for all HIV-positive foreign residents.

39 Prisons Act (Cap 21:03) (Act No 28 of 1979).

40 Attorney General and Others $v$ Tapela and Others, Court of Appeal Civil Case No CACGB-096-14. See also Attorney General and Others v Mwale, Court of Appeal Civil Case No. CACGB-076-15.

41 Prisons Act (Cap 21:03) (Act No. 28 of 1979). 
Kirby JP in stressing the importance of constitutional determinations stressed that constitutional cases are of great moment and are thus brought only in exceptional cases, since:

... the vast majority of disputes can be resolved by reference to the common law and to the statutes enacted by Parliament, and by review proceedings. It is for this reason that it has been consistently held, as $\mathrm{Mr}$ Marcus pointed out, that where a case can be determined without resorting to the Constitution, that is the route which should be followed. ${ }^{42}$

In Ramantele Vs Mmusi \& Others a full bench of the court of appeal had previously stated (per Lesetedi JA at para 41) that:

It is a well-recognized rule of decision-making that where it is possible to decide a case before the Court without having to decide a constitutional question, the Court must follow that approach. ${ }^{43}$

The learned justice had earlier made similar sentiments when at para 22 of the Ramantele case described the doctrine as 'a firm rule of practice', where the words of Kentridge AJ in Mhlungu's case were cited, namely,

I would lay it down as a general principle that where it is possible to decide a case, civil or criminal, without reaching a constitutional issue; that is the course which should be followed. ${ }^{44}$

From an assessment of the ARV case, it was thereby conclusive from the decision of the court, alongside previous determinations of the court that, should any applications or any subsequent appeals arise from the protective provisions of the constitution, these matters could, in future, be determined by applying and interpreting the provisions of any other statute which was relevant to the circumstances. In the particular instance, those of the Prisons Act and the Regulations made thereunder. As a result, there would be no need to address the constitutional questions raised alongside the discussion and findings on these by the judges $a$ quo. Although interesting and pertinent questions were asked of the court, any attempt to address them would be rendered obiter in nature, as the highest court within the jurisdiction refused to recognise and reemphasise the constitutional determinations of the court a quo.

The concept of constitution avoidance undoubtedly presents itself as one of the self-imposed limitations by the judiciary hence, a thorough examination of the said doctrine and its impact on various aspects of law is essential in the study of the law.

42 Court of Appeal Civil case No CACGB-096-14 Para 37.

43 Court of Appeal Botswana case No CACGB-104-12.

44 Mhlungu \& Others 1995 (3) SA 867 (CC) at 895E. See also Ramantele $v$ Mmusi \& Others Court of Appeal Botswana case No CACGB-104-12. 


\section{Room for improvement}

It has been established from the decisions of the courts that they are rather unable to avoid new constitutional danger zones due to the progression of the jurisprudence on human rights and the emergence of new issues to be addressed by the courts. The courts are thereby unsurprisingly forced to create 'constitutional danger zones' when implementing interpretive techniques such as the doctrine in question, which at times leave more questions unanswered.

The savvy avoidance doctrine has allowed the Court on numerous occasions to avoid the effects of its own shifts in constitutional theory; to confront the fact that a statutory problem in such a case is the Court's own creation. The doctrine has been seen to strengthen the Court's ability to sidestep politically controversial decisions, but consequently weaken the intellectual integrity and transparency of the Court's analysis. As an extended consequence, this weakens the political process in so far as constitutional decisions bearing political weight and affecting the democratic landscape is concerned.

The avoidance canon should be applied only when the Court has exhausted other available tools of statutory construction and the reading goes beyond a vague, undefined danger zone into the clearly marked red zone of unconstitutional interpretations, which would distort the legislation in place and the intentions of the only arm of government which enacts legislation. If the Court uses the doctrine as one of last resort, general concerns over the 'delicate and final nature of judicial decisions' would undoubtedly be satisfied. As a doctrine of last resort, the canon still protects statutes and their provisions from invalidation, while also avoiding the reading into existence of socioeconomic rights which were never envisioned by the original drafters of the constitution. The doctrine further protects the jurisprudence from unnecessary declarations with constitutional implications, where other legislation exists to address the issues. When there is doubt, the presumption of constitutionality would apply to also protect the legislation from invalidation. Both tools of construction and interpretation would have their place in application rather than clashing with one another.

Avoiding the avoidance doctrine in this manner also increases the judicial dialogue on constitutional issues. When lower courts invoke the canon to avoid a constitutional issue, it thwarts lower court examination of the constitutional issue and prevents the highest court from benefiting from the lower courts' opinions on the merits of a constitutional claim, thereby undermining the development of the law prior to the highest court weighing in on the issue. Building a judicial dialogue among the judiciary will also alert the legislature of potential problems with its legislation, by giving the legislature an opportunity to weigh in on the matter and clarify its intent. Thus, 
before an issue gets to the court of last resort, the legislature will more likely be aware of the difficulties with a given interpretation and will be capable of responding prior to the Court considering the issue. As a result, leaving use of the avoidance doctrine to courts of last resort would positively increase the dialogue between the judiciary and the legislature.

In order to establish and truly remedy the undesirable aspects of the doctrine of constitutional avoidance, the courts are at liberty to abandon its continued practice or rather adopt more proactive interpretative techniques as was seen in the high court decision in the ARV case. ${ }^{45}$ For there to be a meaningful progression and development in the jurisprudence of the jurisdiction, there is need for clarity in the normative framework and rules of application of section 18 of the Constitution.

Judges have sworn to bring justice to the country, this does not change based on when the judiciary undertakes to uphold human rights by all means available to them. It allows them to do what they see fit, within reasonable limits of course. The instilled trust that is placed in the judicial system and its judgments should be grounds enough for it to stand firm in approaches that do not seem to cower behind application of interpretive doctrines which may be viewed as an abdication of their judicial functions.

\section{Conclusion}

In the interests of preserving judicial independence, the judiciary should be mindful of its traditional role and careful not to step on legislative toes. Regardless of the relative merits and demerits of constitutional avoidance as a judicial strategy and philosophy, the doctrine of constitutional avoidance appears to have a broad following within our jurisdiction.

To the extent that the legislature "punts" to the Court on an issue of constitutional importance, the constitutional avoidance doctrines raises the possibility that the Court may send the "political football" back to the democratic arena and force the political branches to resolve major constitutional questions on their own. In this sense, the avoidance doctrine may be a means of reinforcing and correcting legislative intransigence on major legal issues. However, this may be a risky approach as the appropriate or desired legislative response is not guaranteed especially with due regard of the stream of constitutional challenges the court is faced with regularly. As demonstrated by the criticisms of the avoidance doctrine, the Court's unwillingness to answer major constitutional questions may be 
detrimental as the doctrine often does not operate as a comprehensive or cohesive theory to statutory interpretation. The doctrine of constitutional avoidance cannot be permissible simply to avoid answering difficult moral, social, and political questions altogether as that may amount to failing to execute their mandate. 